\title{
PENGANGKATAN PUTRI MAHKOTA DAN INDIKASI PERGESERAN KONSEP KUASA JAWA: ANALISIS PENDAHULUAN
}

\section{THE APPOINTMENT OF CROWN PRINCESS AND THE SHIFTING OF JA VANESE POWER CONCEPT: A PRELIMINARY ANAL YSIS}

\author{
Kurniawati Hastuti Dewi \\ Pusat Penelitian Politik - LIPI \\ kurniawati.dewi@yahoo.com
}

\begin{abstract}
This paper analyses the awarding title to GKR Pembayun as GKR Mangkubumi, daughter of Sultan HBX of Yogyakarta Court, which indicates her promotion as Crown Princess; the next successor of Yogyakarta Court. Formerly, various socio-political analyses have been raised to understand it. This paper believed that previous analyses are not comprehensive enough, because it did not address power relations of men and women as crucial element of the Javanese concept of power. Therefore, by using gender perspectives, this paper seeks to provide a new understanding of the event, in relations to the role and position of women in Javanese concept of power. Literatur review is the primary method used in this paper. Interview method could not use as the key person recultance to be interviewed due to sensitivity of the issue. This paper reveals that the awarding title of GKR Pembayun as GKR Mangkubumi as Crown Princess indicates changes of Javanese concept of power especialy in relations to women's role and position. In the past, according to the Javanese concept of power, men are perceived as the most suitable and appropriate figure to posess power, now women also perceived as having the same potential as men to posess power. While in past, women are in peripheral position merely due to pro-creation (reproductive) function to give borth for boys as the next successor. Now, women are believed to be able possess power and be a leader in Javanese cosmology. This all happened because the growth of Yogyakarta Court has been surrounding by the current context and challenges of globalization, social Islamisation, democratization, and gender equality.
\end{abstract}

Keywords: Yogyakarta court, crown princess, women, gender equality, Javanese concept of power.

Abstrak

Tulisan ini menganalisis pemberian gelar baru oleh Sultan HB X kepada GKR Pembayun sebagai GKR Mangkubumi yang menandai pengangkatannya sebagai putri mahkota Keraton Yogyakarta dan dipercaya akan menjadi penerus tahta. Beragam analisis sosial dan politik telah dikemukakan mengenai makna pemberian gelar tersebut. Tulisan ini berpendapat bahwa berbagai analisis terdahulu belum sepenuhnya lengkap karena tidak mampu menyajikan analisis yang menyentuh persoalan relasi dan posisi perempuan dan laki-laki sebagai elemen penting dalam konsep kuasa Jawa. Oleh karena itu, dengan menggunakan perspektif gender, tulisan ini memberikan pemahaman baru mengenai makna pemberian gelar baru tersebut dikaitkan dengan peran dan posisi perempuan dalam konsep kuasa Jawa masa kini. Metode penarikan data adalah studi literatur karena permintaan wawancara dengan narasumber kunci tidak dapat dilakukan oleh karena sensitifitas persoalan ini. Tulisan ini menemukan bahwa pemberian gelar baru kepada GKR Pembayun sebagai GKR Mangkubumi mengindikasikan adanya pergeseran konsep kuasa Jawa khususnya terkait peran dan posisi perempuan. Jika pada masa lalu konsep kuasa Jawa mempersepsikan laki-laki sebagai yang paling mampu memiliki potensi kuasa, saat ini perempuan juga telah diposisikan sebagai pihak yang memiliki potensi kuasa sejajar dengan lakilaki. Perempuan yang dahulu berada pada posisi pinggiran dan hanya dibutuhkan karena fungsi prokreasi (reproduksi) untuk melahirkan keturunan laki-laki, kini dipercaya mampu memegang kuasa dan menjadi pemimpin dalam kosmologi Jawa. Pergeseran konsep kuasa Jawa demikian terjadi karena Keraton Yogyakarta tumbuh berkembang dalam konteks kekinian berupa globalisasi, Islamisasi sosial, demokratisasi, dan kesetaraan gender.

Kata kunci: keraton Yogyakarta, putri mahkota, perempuan, keseteraan gender, kuasa Jawa. 


\section{Pengantar}

Pada hari Kamis, 30 April 2015, Raja Keraton Yogyakarta Hadiningrat Sri Sultan Hamengku Buwono X (selanjutnya disebut Sultan HB X) membacakan Sabda Raja yang berbunyi sebagai berikut.

"Gusti Allah Gusti Agung Kuoso Cipto Kawuningono siro kabeh Abdiningsun, putri dalem, sederek dalem, sentono dalem lan Abdi dalem. Nompo weninge dhawuh Gusti Allah Gusti Agung Kuoso Cipto lan romoningsun, eyang eyang ingsun poro leluhur Mataram. Wiwit waktu iki, ingsun nompo dawuh kanugrahan, dawuh Gusti Allah, Gusti Agung, Kuoso Cipto asmo kelenggahan ingsun, Ngarso Dalem Sampeyan Dalem Ingkang Sinuhun Sri Sultan Hamengkubawono Ingkang Jumeneng Kasepuluh Suryaning Mataram Senopati ing Ngalogo Langgenging Bawono Langgenging Toto Panotogomo". Sabdo Rojo iki perlu dimangerteni, diugemi lan ditindakake yo mengkono sabdoningsun.

("Gusti Allah, Gusti Agung, Kuasa Cipta, untuk kalian ketahui semua, abdi saya, putri Sultan, saudara Sultan, kerabat Sultan, dan Abdi Dalem. Saya menerima perintah Gusti Allah, Gusti Agung, Kuasa Cipta, dan ayah saya, kakek-kakek saya, para leluhur Mataram. Mulai saat ini saya menerima perintah kehormatan, Perintah Gusti Allah, Gusti Agung, Kuasa Cipta, nama Kedudukan saya Ngarso Dalem Sampeyan Dalem Ingkang Sinuhun Sri Sultan Hamengkubawono Ingkang Jumeneng Kasepuluh Suryaning Mataram Senopati ing Ngalogo Langenging Bawono Langgenging Toto Panotogomo. Sabda Raja ini perlu dipahami, dipegang teguh, dan dilaksanakan. Begitulah Sabda saya" (Dardias, 2016: 42).

Sabda Raja ini kemudian diikuti dengan pembacaan Dawuh Raja pada 5 Mei 2015, yang berbunyi sebagai berikut.

"Siro abdi ingsun, seksenono Ingsun: Ngarso Dalem Sampeyan Dalem Ingkang Sinuhun Sri Sultan Hamengkubawono Ingkang Jumeneng Kasepuluh, Suryaning Mataram, Senopati ing Ngalogo, Langgenging Bawono Langgeng, Langgenging Toto Panotogomo.Kadawuhan netepake putriningsun Gusti Kanjeng Ratu Pembayun katetepake Gusti Kanjeng Ratu Mangkubumi Hamemayu Hayuning Bawono Langgeng ing Mataram. Mangertono yo mengkono dawuh ingsun (Dardias, 2016: 42).
Untuk menjelaskan maksud dan makna Sabda Raja dan Dawuh Raja, Sultan HB X mengadakan jumpa pers di Ndalem Wironegaran, Jumat 9 Mei 2015. Menurut Sultan, penggantian nama gelarnya adalah "dawuh" atau perintah dari Allah SWT melalui leluhurnya; penggantian nama gelar Sultan tersebut adalah dari "Ngarso Dalem Sampeyan Dalem Ingkang Sinuhun Sri Sultan Hamengkubuwana Senapati in Ngalogo Abdurrahman Sayidin Panatagama Khalifatullah Ingkang Jumeneng Kaping Sadasa ing Ngayogyakarta Hadiningrat" menjadi "Ngarsa Dalem Sampeyan Dalem Ingkang Sinuhun Sri Sultan Hamengkubawono Ingkang Jumeneng Kasepuluh Suryaning Mataram Senapati Ing Ngalogo Langgenging Bawono Langgeng, Langgenging Toto Panotogomo". Sultan HB X menjelaskan secara sederhana tiga perubahan mendasar dalam gelar tersebut adalah sebagai berikut. Pertama, kata "buwono" (jagad kecil, daerah) diganti "bawono" (jagad besar, nasional). Kedua, "kaping sedoso" menjadi "kasepuluh" adalah untuk menunjukkan urutan. Ketiga, penggantian "Abdurrahman Sayidin Panatagama Kalifatullah" diganti "Langgenging Toto Panotogomo" (Rudiana, Antara dikutip dari Tempo.co, Sabtu, 09 Mei 2015).

Berbagai kalangan kemudian menafsirkan peristiwa pemberian gelar baru dari Sultan HB $\mathrm{X}$ kepada putrinya GKR Pembayun dengan gelar Gusti Kanjeng Ratu Mangkubumi, berarti pengangkatannya sebagai putri mahkota, yang akan menjadi penerus tahta Keraton Yogyakarta (Firdaus, Kompas, 6 Mei 2015; Rachmat, Okezone News, 7 Mei 2015; Dardias, 2016). Peristiwa pemberian gelar kepada anak perempuan sebagai putri mahkota yang ditengarai akan menjadi penerus tahta Keraton Yogyakarta, belum pernah terjadi sebelumnya. Hal ini kemudian menimbulkan kontroversi di masyarakat serta perpecahan di antara saudara kandung Sultan HB X. Salah satu penelitian dan analisis mengenai peristiwa ini dilakukan oleh Bayu Dardias (2016) yang fokus pada efektifitas rezim aristokrasi (agraris) Sultan HB X. Dardias menganalisis bahwa atas dasar Sabda dan Dawuh Raja, berarti Sultan HB X telah menunjuk putri sulungnya sebagai penerus tahta Keraton Yogyakarta. Di sini Dardias mengkritisi lemahnya basis legitimasi Sabda dan Dawuh Raja yang semata berdasar petunjuk langit yang kemudian berimplikasi pada melemahnya rezim aristokrasi Sultan HB X. Selain soal lemahnya 
basis legitimasi, beragam analisis muncul dari peristiwa Sabda dan Dawuh Raja. Misalnya, bahwa peristiwa tersebut adalah perebutan kuasa di dalam internal Keraton, sebuah seremoni budaya, atau pertanda memudarnya keistimewaan Yogyakarta. Menurut penulis, peristiwa tersebut dapat dibaca secara berbeda dibandingkan dengan berbagai analisis terdahulu.

Penulis berpendapat kejadian ini dapat ditafsirkan sebagai indikasi pergeseran konsep kuasa Jawa, khususnya terkait peran dan posisi perempuan, pada masa Jawa kontemporer. Penulis mengajukan dua pertanyaan kritis yang muncul dari peristiwa ini dan hendak dijawab oleh tulisan ini. Pertama, bagaimana peristiwa ini menandakan pergeseran konsep kuasa (power) dalam kosmologi Jawa (selanjutnya disebut kuasa Jawa)? Kedua, di manakah posisi perempuan di dalam kemungkinan pergeseran konsep kuasa Jawa tersebut?

Tulisan ini menganalisis peristiwa pemberian gelar baru bagi GKR Pembayun, yang sekaligus menandakan pengangkatannya sebagai Putri Mahkota Keraton Yogyakarta, dengan mengaitkan terhadap kemungkinan pergeseran konsep kuasa Jawa, khususnya pada peran dan posisi perempuan Jawa kontemporer. Buku yang membahas mengenai konsep kuasa Jawa dihubungkan dengan politik Indonesia ditulis oleh Benedict R.O'G. Anderson, The Idea of Power in Javanese Culture (1972a) dan Language and Power: Exploring Political Culture in Indonesia (1990b). Sebagaimana nanti akan dielaborasi lebih mendalam dalam bagian kedua tulisan ini, Anderson mengelaborasi konsep kuasa dikaitkan dengan konteks politik Orde Lama dan awal Orde Baru. Namun, jika dilihat dengan perspektif gender, elaborasi Anderson tampak kurang fair atau tidak seimbang karena contoh-contoh yang dikutip dalam eksplorasi konsep kuasa Jawa menggunakan contoh tokoh laki-laki. Padahal dalam kenyataanya, dalam kosmologi Jawa, banyak perempuan memiliki kekuatan supernatural yang memegang peranan penting dan sangat berpengaruh dalam kuasa dan peradaban Jawa.

Dalam sebuah kesempatan diskusi penulis dengan Anderson (ketika masih hidup) di Universitas Kyoto, Anderson mengamini kritik penulis dan mempersilahkan bagi ilmuwan untuk menggali lebih dalam konsep kuasa Jawa dalam konteks kekinian Indonesia dan dengan menyertakan tokoh-tokoh perempuan di dalamnya. Oleh karena itu, dalam konteks ini, harus ditegaskan bahwa tulisan ini merupakan sebuah analisis pendahuluan, yang harus ditindaklanjuti dengan penelitian lanjutan yang serius untuk mengungkap lebih dalam berbagai temuan awal yang disajikan dalam tulisan ini. Upaya untuk menganalisis dan menafsirkan peristiwa Sabda dan Dawuh Raja dalam koridor konsep kuasa Jawa kontemporer memang sangat urgen dilakukan mengingat masih langkanya studi mengenai hal ini.

Metode utama yang digunakan dalam tulisan ini adalah studi literatur melalui bukubuku, dokumen, bahan-bahan yang membahas konsep kuasa Jawa, yang dikaitkan dengan perkembangan terkini mengenai posisi dan peran perempuan Jawa dalam konteks demokratisasi Indonesia pascaSuharto. Telah dilakukan upaya untuk melakukan wawancara langsung terhadap keluarga inti Sultan HB X untuk memperoleh penjelasan mengenai persitiwa tersebut dikaitkan dengan kemungkinan pergeseran konsep kuasa Jawa. Namun, pada akhirnya wawancara belum dapat dilakukan, dengan alasan masih sensitifnya persoalan ini. Bagian berikutnya akan memaparkan mengenai konsep kuasa Jawa sebagai pijakan dasar.

\section{Memahami Konsep Kuasa dalam Kosmologi Jawa}

Untuk mengetahui posisi perempuan dalam konsep kuasa Jawa, maka terlebih dahulu dielaborasi konsep kuasa Jawa. Bagian ini akan memaparkan elaborasi beberapa ilmuwan yang telah menganalisis konsep kuasa Jawa, diantaranya Benedict R.O'G. Anderson, Koentjaraningrat, G. Moedjanto, dan Mark Woodward.

Salah satu karya yang paling berpengaruh membahas konsep kuasa Jawa ditulis oleh Benedict R.O'G Anderson (1972a) The Idea of Power in Javanese Culture, dan kemudian diteruskan dengan (Anderson, 1990b) Language and Power: Exploring Political Cultures in Indonesia. Dengan mengkontraskan konsep kuasa Jawa dan konsep kuasa dalam literatur barat (western idea of power), Anderson berpendapat bahwa "traditional Javanese culture did have a political theory that offered a systematic and logical explanation of political behavior quite independent of the perspectives of modern political science and in many ways in 
fundamental opposition to them" (Anderson, 1972a: 2; Anderson, 1990b: 18). Anderson mengidentifikasikan konsep kuasa dalam idelologi Jawa berupa "personal inner strength that enable to control himself, other people, supernatural forces, and society rather than exercising physical and military forces" (Anderson, 1972a: 8-13). Konsep ini kemudian disebut sebagai "spiritual potency" oleh Errington (1990: 42).

Menurut Anderson, upaya memperoleh kuasa dapat dilakukan dengan mengumpulkan dan mengonsentrasikan semua energi terdalam, menyerap energi atau kuasa dari luar, dengan melakukan berbagai ritual pengendalian diri untuk mengontrol hawa nafsu dan perilaku (Anderson, 1972a: 8-13). Tanda bahwa seseorang memiliki kualitas penguasaan kuasa adalah ketika yang bersangkutan menjadi halus, elegan, mampu mengendalikan diri, sehingga pada gilirannya dapat mengendalikan kekuatan mistis, mengendalikan kehendak orang lain, dan kehendak masyarakat (Anderson, 1972a: 13, 3839). Catatan Anderson mengenai konsep kuasa Jawa yang menekankan karakter halus sebagai tanda kuasa, sejalan dengan ulasan Errington mengenai konsep kuasa (power) di Asia Tenggara. Errington mencatat bahwa jika dalam konsep pemikiran barat, kuasa dimanifestasikan dalam aktivitas yang nyata dan tampak seperti kontrol ekonomi dan politik (bahkan dengan pengerahan senjata), sedangkan di Asia Tenggara perilaku seperti itu justru dilihat sebagai kurangnya kuasa (a lack of power) (Errington, 1990: 5). Sebagai lawan dari halus, Anderson menjelaskan seseorang yang tidak dapat mengontrol dirinya, tidak dapat mengontrol hawa nafsu, tutur kata, dan perilakunya disebut tidak memiliki kuasa atau kasar (Anderson, 1972a: 38). Menurut Anderson, kasar adalah kualitas dasar seorang laki-laki. Oleh karena itu, perlu ada upaya terus menerus dan berkelanjutan agar seorang lak-laki memiliki kualitas halus sebagai salah satu prasyarat etik mencapai kuasa (Anderson, 1972a: 38).

Selanjutnya Anderson mengungkapkan karakter kuasa dalam ideologi Jawa meliputi kondisi kuasa terkonsentrasi, independen, misterius, energi suci mengatur keseluruhan alam, sumber kuasa homogen karena semua kuasa memiliki jenis dan sumber yang sama, kuasa tidak menimbulkan implikasi moral karena kuasa berasal dari satu sumber yang homogen, kuantum kuasa tetap karena kosmos tidak meluas dan tidak bergejolak (Anderson, 1990b: 21-23). Untuk mencapai kuasa seperti itu, dalam tradisi Jawa diperlukan serangkaian upaya pengendalian diri dengan ritual tertentu seperti puasa, meditasi, tidak melakukan hubungan seksual, melakukan ritual penyucian, memiliki pusaka (seperti keris, tombak, gamelan) yang kemudian kekuatan pusaka tersebut diserap dan memperkuat kekuasaan penguasa (Anderson, 1990b: 23, 27).

Adapun tanda-tanda seseorang memperoleh kuasa adalah ketika seseorang memperoleh wahyu atau disebut juga teja yang memancar dari wajahnya, dan ketika seseorang dapat berperilaku halus, melakukan kontrol pribadi, sopan, sensitif, dan terus menerus mampu mengendalikan diri, berbanding terbalik dengan perilaku yang tidak terkontrol dan kasar (Anderson, 1990b: 32, 50-51). Pada pembahasan mengenai karakter khusus yang dimiliki seseorang yang memiliki kuasa, Anderson mengelaborasi bahwa kemampuan bersikap halus sebagai salah satu tanda penting seseorang memiliki kuasa di Jawa; hal yang umumnya ditemukan pada seorang priyayi (Anderson, 1990b: 50), sebagaimana catatan Geertz bahwa kemampuan bersikap halus sebagai etika dari priyayi (Geertz, 1960a: 229).

Menurut Koentjaraningrat, seseorang di Jawa berpikir kuasa sebagai sebuah kualitas abstrak yang dimiliki seseorang seperti adil tan pilih sih (adil tanpa pilih kasih), wicaksana (bijaksana), dan berbudi tan pamrih (berbuat baik tanpa pamrih) yang merupakan sebuah norma ideal di masyarakat dan memiliki implikasi moral yang dalam (Koentjaraningrat, 1980c: 129-134). Dalam hal kasekten, Koentjaraningrat berpendapat bahwa kasekten dapat diperoleh siapapun yang melakukan ritual tertentu baik seorang yang beragama, orang biasa, maupun pencuri dan penjahat, tetapi orang Jawa tidak akan menganggap pencuri dan penjahat sebagai pemegang kuasa dan layak menjadi pemimpin (Koentjaraningrat, 1980c: 135).

G. Moedjanto menjelaskan konsep kekuasaan Raja-Raja Mataram (1575-1755) bersifat absolut, yang tergambar dalam konsep keagung-binataran. Hal itu berarti bahwa kekuasan raja sangat besar "wenang wisesa ing sanagari" (berwenang tertinggi di seluruh negeri"), tetapi harus pula diimbangi dengan 
kewajiban yang besar pula "ber budi bawa leksana, ambeg adil para marta" (meluap budi luhur mulia dan sifat adilnya terhadap semua yang hidup, atau adil dan penuh kasih) (Moedjanto, 1987: 77-78). Sumber kuasa dari seorang raja berasal dari keajaiban sebagai tanda restu leluhur, disertai dengan penguasaan yang bersangkutan terhadap sumber kasekten (kesaktian) berupa pusaka (Moedjanto, 1987: 123-124). Dalam tataran ideal seorang raja, puncak kuasa seorang raja diekspresikan ke dalam frase jumbuhing kawula-gusti menggambarkan seorang raja mampu memahami kehendak rakyat seraya menggambarkan menyatunya hubungan antara raja dengan Tuhan (Moedjanto, 1987: 82). Namun, menyimak catatan tambahan dari Moedjanto (1987: 110) bahwa frasa ini juga bermakna bahwa ketaatan rakyat terhadap raja haruslah seperti ketaatan manusia pada Tuhan, maka menurut penulis frasa ini juga sangat politis karena membangun hegemoni relijiuskultural-politis tentang ketaatan total rakyat pada kuasa Raja Yogyakarta.

Salah satu manifestasi keagungbinataran adalah penggunaan gelar untuk memadukan kuasa budaya dan agama dalam satu tangan seperti dalam gelar Senapati ing Ngalaga Sayidin Panatagama Khalifatullah. Moedjanto (1987: 122) mencatat gelar Sultanyang berasal dari bahasa Arab-telah dipilih dipakai oleh raja Yogyakarta Pangeran Mangkubumi pendiri Kesultanan Yogyakarta yang kemudian bergelar Sultan Hamengku Buwana I, sedangkan Raja Surakarta memilih memakai gelar Susuhunan (Sunan). Peristiwa ini, menurut penulis, dapat dilihat sebagai salah satu manifestasi masuknya pengaruh ketuhanan ajaran Islam, minimal secara simbolis dalam konsep kuasa Jawa.

Mark R. Woodward menjelaskan konsepsi kuasa Jawa, yang menurutnya sangat erat kaitannya dengan kasekten sebagai sebuah konsep Hindu Jawa, yang di dalam konsep tersebut posisi kasekten lebih rendah daripada wahyu dari Tuhan (Woodward, 1989: 200-225). Menurut Woodward, kepemilikan kuasa memerlukan sumber kuasa, seperti kepemilikan pusaka dan meditasi (bertapa) untuk mendapatkan kuasa dan kemenyatuan dengan Tuhan (Woodward, 1989: 227). Dalam mengelaborasi asal usul konsep kepemilikan kuasa dalam tradisi Jawa, Woodward memaparkan pandangan menarik berangkat dari perspektif sejarah Islam di Jawa. Woodward berpendapat bahwa para pedagang muslim dan para guru sufi yang menyebarkan Islam ke Jawa sangat terbiasa dan familiar dengan praktik bertapa yang menjadi landasan dasar konsep kuasa Jawa. Oleh karena itu, elemen HinduJawa ini harus di-Islamkan sehingga kekuatan magis harus didapat dengan kombinasi normanorma kesalehan Islam dan mistik sufi (Woodward, 1989: 231).

Meskipun terdapat poin ketidaksamaan dalam elaborasi mengenai konsep kuasa Jawa di antara Anderson, Koentjaraningrat, G. Mudjanto, dan Woodward, seperti pada pada aspek karakter alami kuasa dan apakah kuasa memiliki implikasi moral, namun keempatnya memiliki kesamaan dalam mengulas sumber kuasa Jawa, yaitu kuasa dalam konsep dan kosmologi Jawa adalah sesuatu yang didapat secara misterius dan berasal dari sumber suci diberikan oleh Tuhan berupa wahyu yang hanya dapat diperoleh melalui praktik ritual tertentu yang membutuhkan akumulasi energi sekitar, mempertahankan kekuasaan melalui kasekten, memiliki pusaka, dan pada taraf tertentu memperoleh dukungan dari pemuka agama seperti resi, begawan, ajar, kyai, wali.

Pada titik tertentu, konsep kuasa di Jawa selalu dikaitkan dengan priyayi karena dianggap yang paling mampu berperilaku dan memiliki kulitas halus sebagai tanda kuasa dalam kultur Jawa. Pada titik inilah, konsep yang begitu lekat antara kuasa Jawa dengan perilaku priyayi ternyata menunjukkan bahwa laki-laki dipersepsikan sebagai yang paling mampu dan cocok memegang kuasa Jawa. Mengapa demikian? Hal ini karena dalam konsepsi pemikiran Jawa mengenai peran perempuan, Dajadiningrat-Nieuwenhuis (1987: 47) mencatat bahwa perempuan lebih banyak dihubungkan dengan kegiatan yang bersifat sosial dan material sehingga tidak cocok untuk praktik ritual tertentu yang membutuhkan kontrol diri yang bagus, dan hanya beberapa kasus pengecualian ketika perempuan memiliki kekuatan batin yang luar biasa untuk memperoleh kuasa. Lalu, di manakah sebenarnya posisi perempuan dalam konsep kuasa Jawa tersebut? Bagian berikutnya akan mengelaborasi lebih mendalam mengenai hal ini. 


\section{Posisi Perempuan dalam Konsep Kuasa Jawa}

Mendiskusikan mengenai di mana posisi perempuan dalam konsep kuasa Jawa mengharuskan kita melihat elaborasi para ilmuwan, khususnya terkait budaya Jawa dan gender, yang di dalamnya juga menyinggung persoalan kuasa Jawa. Studi antropologi Hildred Geertz (1961b: 2-3.) di Modjokuto mengupas sistem kekerabatan (kinship system) keluarga Jawa. Penelitiannya didasarkan pada asumsi bahwa sistem kekerabatan keluarga Jawa, tempat keluarga inti menjadi unit dasar, memegang peranan penting menjaga stabilitas dan kelangsungan masyarakat Jawa. Hildred Geertz menawarkan konsep atau istilah bilateral sebagai struktur utama dalam sistem kekerabatan Jawa dan matrifocal sebagai struktur kedua dari sistem kekerabatan Jawa (Geertz, 1961b: 78). Bilateral adalah sistem ketika keturunan dari garis bapak maupun ibu diperlakukan sama, termasuk saudara kandung dari kedua garis menerima warisan secara sama besar. Sementara itu, matrifocal adalah jaringan kekerabatan antarperempuan yang masih satu saudara (network of ties between related women) (Geertz, 1961b: 78). Dengan matrifocal, Geertz menegaskan bahwa perempuan Jawa memiliki peran yang penting dalam sebuah keluarga Jawa karena perempuan memiliki otoritas, pengaruh, dan tanggung jawab lebih besar daripada suaminya, dan pada saat bersamaan lebih diapresiasi dan dituruti (Geertz, 1961b: 79). Geertz percaya bahwa perempuan Jawa memiliki status dominan dalam keluarga Jawa karena pengaruh emosional dan kemampuan ekonomi yang relatif otonom (Geertz, 1961b: 46, 79-80).

Namun demikian, Koentjaraningrat (1962b: 874) mempertanyakan catatan Hildred Geertz mengenai matrifocality dengan mengatakan bahwa itu hanya terjadi pada keluarga Jawa kelas bawah di daerah pedesaan, perkotaan, atau pusat kota, tetapi tidak ditemui pada keluarga perempuan kelas priyayi. Koentjaraningrat (1957a: 89) melakukan penelitian pada keluarga priyayi di Jawa bagian selatan dan menyimpulkan bahwa pembagian kerja secara seksual benar-benar terjadi. Suami menjadi pemimpin keluarga, dengan tugas utama menyelesaikan persoalan berkaitan dengan urusan luar, dan jarang terlibat dengan persoalan rumah tangga yang menjadi tanggung jawab istrinya. Meskipun Robert R. Jay (1969b: 89) juga setuju dengan catatan Hildred Geertz tentang matrifocality, tetapi Jay memberikan catatan penting yang harus diperhatikan, yaitu meskipun hubungan suami istri dalam keluarga Jawa menunjukkan peran saling melengkapi antara laki-laki dan perempuan (complementary roles of male and female), tetapi ideologi tradisional Jawa tetap mempercayai bahwa lakilaki adalah pemegang otoritas utama dan terakhir dalam sebuah keluarga.

Studi antroplogi Sullivan (1994: 113) mengenai kehidupan keluarga Jawa kelas bawah di daerah perkotaan Sitiwaru (nama samaran) sebuah kampung di jantung Kota Yogyakarta, menolak Hildred Geertz (1961b) bahwa perempuan Jawa memiliki pengaruh besar dalam keluarga. Temuan di Sitiwaru menunjukkan bahwa meskipun para perempuan memiliki tanggung jawab lebih dan memberikan kontribusi ekonomi yang banyak, mereka tidak memiliki kewenangan dan pengaruh melebihi suami mereka. Selanjutnya, Sullivan (1994: 9) berpendapat bahwa matrifocality adalah merefleksikan kewenangan laki-laki sebagai pemegang kendali utama dalam rumah tangga (male power as the master of the Javanese household), sementara perempuan hanya sekedar manajer saja (while women are only manager).

Sampai dengan poin ini, melalui konsep matrifocality, paling tidak diketahui bahwa dalam sebuah konsep keluarga Jawa, perempuan memiliki kendali atas pengaturan rumah tangga, tetapi tetap laki-laki menjadi kepala keluarga dan menjadi wakil keluarga dalam mengurusi persoalan yang berkaitan dengan dunia luar. Matrifocality ini tampaknya juga memiliki wajah dan praktik yang berbeda antara perempuan kelas bawah dan perempuan priyayi ketika perempuan kelas bawah memiliki derajat otonomi lebih besar untuk mengendalikan rumah tangga, termasuk memiliki kemandirian ekonomi, dibandingkan dengan perempuan priyayi.

Di luar konsep matrifocality, pada umumnya para ilmuwan mencatat bahwa dalam konsepsi kuasa Jawa, perempuan dipandang lebih rendah dibandingkan laki-laki untuk memiliki kuasa. Ward Keeler (1990: 130) berpendapat bahwa meskipun perempuan Jawa memegang peran penting dan sentral dalam mengatur rumah tangga, memiliki kemandirian ekonomi, diuntungkan dengan fleksibilitas dalam menjalankan peran gender yang saling 
melengkapi dengan laki-laki, tetapi perempuan Jawa selalu dipersepsikan kurang memiliki kualitas penting untuk memiliki kuasa, seperti tidak mampu mengontrol diri (tidak sabar) dan tidak memiliki potensi spiritual/kapasitas mistis; kualitas yang pada umumnya melekat dan dimiliki - meskipun tidak hanya terbatas padalaki-laki.

Suzanne A. Brenner (1995: 31) juga mencatat hal yang serupa dengan Keeler dan menyebut adanya "categorical statements about the nature of the sexes" di Jawa. Dia mengemukakan bahwa laki-laki digambarkan memiliki kemampuan spiritual yang tinggi untuk mempertahankan keteraturan di dalam hidup mereka dan masyarakat sosial, sedangkan perempuan digambarkan tidak memiliki potensi spiritual dan kurang memiliki kemampuan pengendalian diri. Lebin lanjut, Brenner menuturkan pengkategorian seperti ini mengakibatkan laki-laki selalu ditempatkan pada pusat kendali sosial dan politik di tingkat lokal dan nasional, sedangkan perempuan dikesampingkan dan tidak mampu mengambil peran politik. Hampir sejalan dengan Brenner, Kathryn Robinson (2009: 30) juga mencatat mengenai "the ideological devaluing of women and femininity in Java". Dia mengemukakan bawah perempuan dianggap lebih rendah daripada laki-laki karena perempuan tidak memiliki kualitas kuasa Jawa, yaitu pengendalian diri yang baik, tidak memiliki potensi sipiritual sehingga mereka tidak mampu menjalankan berbagai lelaku ritual untuk memperolah kekuatan spiritual dan kuasa, jika dibandingkan dengan laki-laki.

Posisi yang menarik juga dicatatkan oleh Clifford Geertz berkaitan dengan halus dan kasar yang menjadi atribut yang melekat pada stratifikasi kelas sosial di Jawa. Halus adalah etika atau perilaku seorang kelas priyayi, sementara kasar adalah atribut atau perilaku kelas bawah (petani, buruh, pedagang) (Geertz, 1960a: 229). Geertz berpendapat bahwa priyayi Jawa memiliki standar atau pandangan spesifik mengenai kualitas halus sebagai yang tertata, teratur, mewah, beradab, dan lembut (refined, polished, exquisites, civilized, smooth), berkebalikan dengan kasar sebagai tidak sopan, kasar, tidak beradab, dan murahan (impolite, rough, uncivilized, a cheap piece of cloth) (Geertz, 1960a: 232). Geertzs memang tidak secara langsung menggunakan kasar dan halus untuk mengasosiasikannya dengan perempuan dan laki-laki. Namun, posisi Geertz tampak sama dengan catatan Keeler dan Brener. Geertz mengatakan "a man who speaks flawless highJavanese is alus, as is the high-Javanese itself" (Geertz, 1960a: 232), dan ketika berbicara mengenai mistik (mysticism) dikatakan bahwa "the general opinion is that mysticism is more difficult for them [women, perempuan, diperjelas penulis], given their inherently less peaceful nature (Geertz, 1960a: 329)".

Pandangan dalam ideologi kuasa Jawa bahwa perempuan tidak memiliki kualitas untuk memperoleh kuasa karena kasar, ternyata diperkuat oleh persepsi bahwa ketrampilan dan dominasi perempuan Jawa dalam hal keuangan, berdagang, dan aktivitas ekonomi, dianggap menunjukkan rendahnya kualitas perempuan. Perempuan Jawa memang memiliki banyak peran di bidang keuangan, ekonomi, dan perdagangan, seperti dicatat oleh Hildred Geertz (1961b: 46) dan juga Vreede-De Stuers (1960). Catatan Brenner (1995: 26) dan Geertz (1960a: 229) juga memperlihatkan bahwa ideologi Jawa melihat persoalan uang dan aktivitas ekonomi, terutama ketika perempuan banyak memegang peranan penting dilihat sebagai yang tidak beradab atau pekerjaan kasar, dan menunjukkan status rendah perempuan Jawa. Menurut Barbara Hatley (1990: 182), meskipun perempuan Jawa mungkin mampu melakukan ritual tertentu seperti meditasi dan sejenisnya, tetapi mereka tetap dipersepsikan sebagai yang tidak mampu mengontrol tutur kata dan emosinya, merefleksikan kekuatan spiritual yang rendah, dan secara tidak langsung biasanya disebut dengan karakter yang kasar.

Sampai pada titik ini, dapat dimengerti bahwa ternyata dalam ideologi kuasa Jawa perempuan menempati posisi pinggiran karena dipersepsikan tidak memiliki potensi spiritual yang tinggi untuk dapat melakukan berbagai lelaku ritual untuk memperolah kekuatan magis, memperoleh kuasa, menyerap kekuatan dari luar, kualitas dasar perempuan adalah tidak mampu mengontrol diri dan tutur kata, dan lebih menonjol dengan karakter kasar. Padahal, untuk memperoleh kuasa Jawa dibutuhkan karakter halus yang dianggap lebih melekat dan dimiliki laki-laki. Pandangan yang mendiskreditkan perempuan dalam kuasa Jawa semakin diperparah dengan pandangan bahwa aktivitas ekonomi, perdagangan, dan yang berhubungan dengan uang yang biasa dikendalikan dan dilakukan perempuan justru dianggap aktivitas 
kasar sehingga semakin menjauhkan perempuan dari kemampuan memperolah kuasa Jawa. Implikasinya adalah, dapat dimengerti jika kemudian dalam sejarah Keraton Yogyakarta, sebagai titik pusat budaya dan kuasa Jawa, seluruh para pewaris tahta adalah laki-laki.

Namun, ternyata terdapat perkembangan baru yang belum pernah terjadi selama ini. Sebagaimana dikemukakan pada bagian awal, belum lama ini Sultan HB X mengangkat GKR Pembayun menjadi Putri Mahkota Keraton Yogyakarta. Lalu bagaimana seharusnya fenomena ini dibaca, jika dikaitkan dengan konsep kuasa Jawa kontemporer? Apakah hal ini menandakan pergeseran konsep kuasa Jawa? Untuk menjawab hal ini, terlebih dahulu akan dielaborasi mengenai dinamika sosial terkait status keistimewaan Yogyakarta dalam konteks terkini Indonesia.

\section{Dinamika Sosial "Keistimewaan Yogyakarta": Konteks Terkini}

Pasal 18B ayat 1 UUD 1945 menghormati keragaman, kekhususan, dan keistimewaan daerah-daerah di Indonesia dalam bingkai negara kesatuan, yang melahirkan desain pemilihan kepala daerah sebagai pilkada "asimetris", sebagaimana terjadi di Provinsi Daerah Istimewa Yogyakarta, Daerah Istimewa Aceh, dan Provinsi Papua Barat (Djohan, 2013). Daerah Istimewa Yogyakarta adalah salah satu daerah istimewa karena kekhasan budaya dan kontribusi daerah ini dalam sejarah perjuangan kemerdekaan Indonesia. Pemerintah Pusat telah memberikan predikat dan perlakuan istimewa kepada Yogyakarta sesuai dengan UndangUndang Keistimewaan (UUK) Yogyakarta No. 13/2012. Salah satu bentuk keistimewaan adalah bahwa Raja Yogyakarta yang merupakan pemimpin kultural, secara otomatis menjadi gubernur yang merupakan jabatan politis dalam struktur pemerintahan daerah. Dalam konteks demokratisasi, pernah terjadi gugatan terhadap status keistimewaan Yogyakarta. Seorang pengacara Muhammad Sholeh yang berasal dari Jawa Timur, mengajukan gugatan ke Mahkamah Konstitusi (MK) untuk menguji beberapa pasal UUK Yogyakarta No. 13/2012, di antaranya Pasal 18 ayat 1 (c) yang menyatakan syarat menjadi gubernur dan wakil gubernur Jogjakarta "harus bertakhta sebagai Sultan Hamengku Buwono untuk calon gubernur dan bertakhta sebagai Adipati Paku Alam untuk calon wakil gubernur". Menurut Sholeh, pasal tersebut menghalangi hak konstitusionalnya - sebagaimana dijamin Pasal 18 ayat (4) dan Pasal 18B ayat (1) UUD 1945-untuk dapat dicalonkan menjadi gubernur maupun wakil gubernur Yogyakarta. Menurutnya, sebagai warga negara Indonesia, dirinya berhak dicalonkan menjadi gubernur maupun wakil gubernur manapun (tribunmadura.com, 19 Agustus 2016). Namun, pada akhirnya gugatan tersebut ditolak MK dan Yogyakarta tetap memperoleh status keistimewaan dalam pengangkatan kepala daerah.

Selain menghadapi dinamika dari luar, terdapat dinamika dari dalam mengenai menerjemahkan keistimewaan Yogyakarta dalam konteks kontemporer. Undang-Undang Keistimewaa Yogyakarta telah mengatur bahwa untuk menjadi Gubernur DIY haruslah raja Yogyakarta, dan juga laki-laki. Pasal 18 Ayat (1) UUK Yogyakarta, yang secara tersirat mengindikasikan bahwa kepala daerah DIY haruslah dijabat seorang laki-laki, berbunyi: "calon gubernur DIY menyerahkan daftar riwayat hidup yang memuat antara lain riwayat pendidikan, pekerjaan, saudara kandung, istri, dan anak". Pasal ini secara ekplisit mengatakan bahwa syarat menjadi calon gubernur DIY adalah laki-laki, karena mensyaratkan calon gubernur untuk menyerahkan daftar riwayat hidup istrinya.

Dalam sejarahnya, sejak Sri Sultan HB I sampai HB X yang diangkat menjadi raja, dan kemudian menjadi Gubernur Yogyakarta, selalu laki-laki. Gambar 1 di bawah ini menggambarkan silsilah Raja Mataram Yogyakarta. 
Gambar 1. Silsilah Raja Keraton Yogyakarta

Sultan Hamengku Buwono I (1755-1792)

Lahir BRM Sujono (1717), putra Sunan Amangkurat IV

Sultan Hamengkubuwono II

(1792-1810; 1811-1812; 1826-1828)

Lahir GRM Sundoro (1750), putra Sultan Hamengkubuwono I

Sultan Hamengkubuwono III

(1810-1811; 1812-1814)

Lahir GRM Suroyo (1769), putra Sultan Hamengkubuwono II

Sultan Hamengku Buwono IV (1814-1823)

Lahir GRM Ibnu Jarot (1804), putra Sultan Hamengkubuwono III

$\checkmark$

Sultan Hamengku Buwono V (1823-1826; 1828-1855)

Lahir GRM Gathot Menol (1820), putra Sultan Hamengkubuwono IV

Sultan Hamengku Buwono VI (1855-1877)

Lahir GRM Mustodjo (1821), putra Sultan HB IV, adik Sultan Hamengkubuwono V

Sultan Hamengku Buwơno VII (1877-1921)

Lahir GRM Murtedjo (1839), putra Sultan Hamengkubuwono VI

Sultan Hamengku Buwono VIII (1921-1939)

Lahir GRM Sudjasi (1880), putra Sultan Hamengkubuwono VII

Sultan Hamengku Buwono IX (1939-1988)

Lahir GRM Dorojatun (1912), putra Sultan Hamengkubuwono VIII

Sultan Hamengku Buwono X (1989-sekarang)

Lahir GRM Herjuno Darpito (1946), putra Sultan Hamenkubuwono IX

Sumber: (Kristanto, 8 Mei 2015)

Sebagaimana gambar di atas, tidak pernah ada dalam sejarah Keraton Yogyakarta, terdapat Ratu (raja perempuan). Hal ini tidak mengherankan jika kita memahami konsepsi kuasa dalam kosmologi Jawa sebagaimana telah diulas sebelumnya. Sebagaimana dicatat Moedjanto (1987: 101, 109), sistem politik kerajaan Mataram Yogyakarta pada dasarnya adalah sistem politik patrimonial. Dalam sistem ini, pewarisan tahta adalah menurut garis ayah, yang mementingkan laki-laki daripada perempuan sebagai pewaris tahta; raja adalah seorang bapak, mulia, memiliki kuasa seperti dewa, sebagai sumber segala kebaikan, kemakmuran, keadilan, kesejahteraan dan pelindung semua orang sebagaimana tercantum dalam Babad Tanah Djawi, Serat Centhini, dan Wulangreh. Sistem politik patrimonial kerajaan Mataram, yang mementingkan laki-laki daripada perempuan sebagai pewaris tahta kerajaan, sejalan dengan konsep kuasa Jawa.
Sebagaimana telah diekplorasi sebelumnya, dalam konsep Jawa perempuan dipersepsikan sebagai yang tidak mampu mengontrol tutur kata dan emosinya, kasar, sehingga merefleksikan kekuatan spiritual yang rendah, sedangkan laki-laki dipercaya lebih mampu menjalankan berbagai lelaku ritual untuk memperolah kekuatan spiritual dan pengendalian diri yang baik. Memahami sistem politik patrimonial kerajaan Mataram dan melihat fakta bahwa semua raja selama ini adalah laki-laki, maka pemberian gelar GKR Pembayun menjadi GKR Mangkubumi yang menjadikan putri Sultan menjadi putri mahkota sebagai pengganti Sultan, memang tidak sejalan dengan tradisi dan sejarah Keraton Yogyakarta selama ini.

Dalam kondisi tidak menentu seperti ini, Dewan Perwakilan Rakyat (DPRD) DIY melalui rapat paripurna 30 Maret 2015, mengesahkan Rancangan Peraturan Daerah Keistimewaan 
(Raperdais) yang menetapkan bahwa pengisian jabatan Gubernur Yogyakarta harus dari kalangan laki-laki. Tujuh fraksi di DPRD DIY sepakat menyatakan pandangan mengenai Pasal 3 (m) tentang persyarataan calon gubenur disesuaikan seperti bunyi Pasal 18 Ayat (1) UU Keistimewaan No. 13/2012. Dalam Pasal 18 Ayat (1) UU Keistimewaan Yogyakarta, yang menegaskan jabatan kepala daerah DIY harus dijabat oleh laki-laki, berbunyi "calon gubernur DIY menyerahkan daftar riwayat hidup yang memuat antara lain riwayat pendidikan, pekerjaan, saudara kandung, istri, dan anak." Pasal ini secara tersirat memperlihatkan bahwa syarat menjadi calon gubernur DIY adalah lakilaki. Oleh karena itu, Sultan HB X mengungkapkan harapannya agar pasal di UU Keistimewaan Yogyakarta maupun Raperdais yang memuat persyaratan tersebut direvisi agar tidak diskriminatif (Antara, sebagaimana diakses dari Kompas.com, Rabu, 1 April 2015). Kendati sempat terjadi perbedaan pendapat di antara beberapa anggota dewan, pada akhirnya Raperdais Tata Cara Pengisian Jabatan Gubernur dan Wakil Gubernur DIY disahkan (disepakati 42 anggota dewan dari 55 anggota DPRD dan dihadiri Sri Sultan HB X) oleh DPRD sejalan dengan UU Keistimewaan Yogyakarta pada 31 Maret 2015, yang berarti DPRD menutup peluang seorang perempuan menjadi Gubernur DIY (Rachmat, 7 Mei 2015).

Perkembangan baru terjadi kemudian, pada bulan November 2016 sejumlah elemen masyarakat Yogyakarta, di antaranya abdi dalem Keraton Ngayogyakarta, perangkat desa, pegiat anti diskriminasi hak asasi perempuan, serta aktivis perempuan, melakukan gugatan uji materi ke MK atas pasal 18 ayat 1 (m) UU Keistimewaan DIY, yang berbunyi, "calon gubernur dan calon wakil gubernur adalah warga negara Republik Indonesia yang harus memenuhi syarat: $m$. menyerahkan daftar riwayat hidup yang memuat, antara lain riwayat pendidikan, pekerjaan, saudara kandung, istri, dan anak". Dalam pandangan penggugat, ayat ini diskriminatif terhadap perempuan, karena frase "istri" menimbulkan penafsiran seolaholah harus laki-laki yang menjadi Gubernur Daerah Istimewa Yogyakarta (Fachrudin, 17 November 2016). Hal ini sejalan dengan pemikiran Sultan HB X, yang menambahkan bahwa syarat calon kepala daerah harus menyerahkan daftar riwayat hidupnya lebih tepat diterapkan dalam konteks pemilihan kepala daerah secara langsung atau tidak langsung, dan tidak lazim diterapkan dalam pengisian jabatan gubernur dan wakil gubernur di DIY, karena seluruh rakyat telah mengetahui profil sultan dan adipati yang bertahta di DIY (kabarkota.com, 18 November 2016).

Jadi, dapat dilihat bahwa pada saat yang bersamaan terdapat dinamika dari luar yang menggunggat Keistimewaan Yogyakarta. Sementara itu, pada saat yang sama, Sultan dan masyarakat Yogyakarta sedang memperdebatkan soal kriteria calon gubernur dan wakil gubernur DIY terkait erat dengan persoalan kiprah perempuan untuk menjadi pemimpin publik. Perdebatan itu dengan sendirinya menyinggung persoalan kesetaraan dan keadilan gender dalam konsep kuasa Jawa di dalam (dan di luar) Keraton Yogyakarta. Lalu, bagaimana peristiwa pengangkatan Putri Mahkota Keraton Yogyakarta dapat ditengarai sebagai sebuah pertanda pergeseran konsep Kuasa Jawa?

\section{Pengangkatan Putri Mahkota Keraton Yogyakarta: Pergeseran Konsep Kuasa Jawa?}

Transisi dari masa kejayaan Kerajaan Hindu-Budha di Jawa Timur (Kerajaan Majapahit yang berhasil menyatukan Daha (Kediri) dan Singasari) ke masa awal hegemoni Kerajaan Mataram Islam terjadi pada akhir abad ke-15 dan awal abad ke-16 (Florida,1995: 9). Pergantian dari Hindu Jawa ke Islam diprakarsai oleh para wali sebagai generasi pertama penyebar Islam di pantai utara Jawa seperti Ngampel, Gresik, Demak, Tuban, Jepara, dan Cirebon (Jay, 1963a: 6). Telah banyak dimengerti bahwa Kerajaan Islam pertama di Jawa adalah Demak yang didirikan oleh Raden Patah atau Panambahan Djinbun pada sekitar tahun 1500. Kemudian, terjadi konflik antara Kerajaan Pajang (Islam Jawa) dan Jipang (Islam ortodoks) kemudian kemenangan Pajang mengakhiri dominasi Demak; dalam perkembangannya Pajang berhasil diruntuhkan oleh oleh Kerajaan Mataram (Moedjanto, 1987: 28). Sejak 1975, Senopati, Raja pertama Kerajaan Mataram, membangun pusat negara di dekat daerah yang saat ini merupakan Kota Yogyakarta. Beliau membangun kekuatan di seluruh Jawa Tengah dan Jawa Timur untuk mengalahkan kekuatan para penguasa di pantai utara Jawa dengan menggunakan kekuatan militer (Jay, 1963a: 9). Menurut Jay (1963a: 9) untuk membendung penyebaran Islam, penguasa dan para petinggi 
Kerajaan Mataram mempromosikan sebuah konsep berupa mengawinkan antara agama Islam dengan Hindu-Buddha sebagai agama resmi negara.

Lebih lanjut, Woodward (1989: 3) mengatakan bahwa penyebaran dan penetrasi Islam di Jawa terjadi begitu cepat karena Islam digunakan oleh para penguasa kerajaan sebagai basis membentuk negara teokrasi ("it was embraced by the royal courts as the basis for a theocratic state"). Kerajaan Mataram yang tidak dapat membendung perkembangan Islam membuat kompromi untuk mempertahankan nilai dan kepercayaan budaya Jawa-bahwa Islam hanyalah wadah (container), sementara kehidupan spiritual terdalam tetap merupakan budaya Jawa (Koentjaraningrat, 1980b: 131). Hal serupa juga dicatat oleh Woodward (1989: 3) yaitu formulasi of Islam Jawa yang berarti wadah (container) adalah alam semesta, negara, tubuh fisik, dan norma-norma kesalehan santri, sementara isinya (content) adalah mistik, sultan, sebagai jiwanya (the mysticism, the sultan, the soul).

Menurut catatan Niels Mulder (2001: 42), sebuah keraton mencerminkan tatanan kosmos yang memancarkan keberkahan ilahi bagi para penduduknya dan kerajaanya. Di dalam sebuah keraton, para raja dianggap merupakan anasir mistik paling sakti di bumi ini, sebagai 'wadah' potensi kosmis yang kekuasaan duniawinya mencerminkan kharismanya ditunjukkan dalam kemampuan menerima wahyu/wangsit sebagai pertanda kekuatan magis pribadinya kepada rakyat untuk menjamin kesejahteraan rakyat (Mulder, 2001: 40). Sesuai dengan pengertian ini maka dapat dipahami bahwa posisi raja-raja Keraton Yogyakarta dipandang memiliki posisi sebagai wakil Tuhan di dunia yang mengatur kosmos atau alam semesta, yang nantinya tecermin dalam gelar yang disandangnya. Salah satu manifestasi pengaruh agama Islam masuk ke dalam kerajaan Mataram Yogyakarta adalah gelar Khalifatullah bahwa seorang raja adalah juga kepanjangan tangan Tuhan.

Meskipun kental dengan pengaruh Islam, tetapi elemen ritual Hindu terasa dalam pengangkatan seorang raja. Sebelum seseorang diangkat menjadi raja, biasanya didahului dengan penyerahan pusaka Keraton berupa keris Kyai Jaka Piturun yang selalu diserahkan raja kepada seseorang yang diinginkan menjadi putra mahkota dan kelak menjadi Sultan Keraton Yogyakarta (Mochtar dalam Atmakusumah 1982: 37; sebagaimana dikutip dari Wardani, 2012: 58). Hal itu misalnya terlihat pada prosesi penyerahan pusaka Kyai Jaka Piturun kepada Gusti Raden Mas Dorodjatun (nama asli Sultan Hamengku Buwana IX) yang berarti penyerahan tahta Keraton Yogyakarta kepada Sultan yang baru, dan setelah dinobatkan menjadi raja bergelar "Sampeyan Dalem Ingkang Sinuwun Kanjeng Sultan Hamengkubuwono Senopati Ing Ngalogo (panglima angkatan perang) Ngabdurrakhman Sayidin Panatagama (pimpinan agama dan wakil Tuhan di bumi) Khalifatullah IX" (Khairuddin 1995: 35; sebagaimana dikutip dari Wardani, 2012: 58).

Hal yang kurang lebih sama terjadi pada GKR Pembayun. Pada Selasa Wage, 5 Mei 2015, GKR Pembayun menerima Dawuh Raja Sultan HB X dengan duduk di kursi yang berada di atas Watu Gilang, untuk memperoleh gelar baru sebagai GKR Mangkubumi. Watu Gilang adalah batu bekas singgasana pendiri Mataram Panembahan Senopati, dan tidak sembarangan orang diperbolehkan duduk di atasnya (detiknews, 11 Mei 2015). Hanya seseorang yang diangkat sebagai putra mahkota yang berarti akan menjadi penerus tahta Keraton Yogyakarta yang diperbolehkan duduk di atasnya sebagaimana fakta bahwa Watu Gilang tidak pernah diduduki siapa pun sejak HB X diangkat sebagai putra mahkota pada 7 Maret 1989 (Jppn.com, Kamis, 14 Mei 2015). Lalu, bagaimana peristiwa ini dapat ditafsirkan sebagai tanda-tanda pergeseran konsep kuasa Jawa?

Pertama, harus dipahami bahwa konteks sosial raja-raja Mataram Yogyakarta sampai dengan Sultan HB X yang kesemuanya laki-laki, berbeda dengan konteks saat ini ketika peristiwa pengangkatan GKR Pembayun sebagai putri mahkota terjadi. Menurut penulis, saat ini telah terjadi perubahan konteks sosial yang luar biasa yang melingkupi pertumbuhan dan perubahan Keraton Yogyakarta, terutama pasca1998 (setelah kejatuhan Suharto). Periode bulan madu sinkretisme Hindu dengan Islam dalam Keraton Yogyakarta, sejak peradaban Jawa paling tidak sejak perkembangan Mataram Islam 1975 sampai saat ini, telah mulai bergeser. Sebagaimana telah dijelaskan sebelumnya, Kerajaan Mataram Islam Yogyakarta yang tidak dapat membendung perkembangan Islam membuat kompromi untuk mempertahankan 
nilai dan kepercayaan budaya Jawa-bahwa Islam hanyalah wadah sementara kehidupan spiritual terdalam tetap merupakan budaya Jawa (Koentjaraningrat, 1980b: 131).

Dalam konteks kekinian, Masaaki, Atsushi, dan Suaedy (2010: 3) menyebut fenomena "Islamisasi sosial" atau "social Islamization" yang begitu dahsyat terjadi sejak keruntuhan Suharto ketika semakin banyak Muslim berlomba-lomba untuk mendalami atau mempraktikkan norma-norma Islam dalam kehidupan keseharian. Di tengah perubahan konteks sosial sedemikian derasnya, berupa kuatnya arus Islamisasi sosial, Keraton Yogyakarta tampaknya justru perlahan mulai melepaskan simbol-simbol kedekatan dengan nilai-nilai Islam. Sebagai contoh, pada Kamis 30 April 2015, Sultan HB X membacakan Sabda Raja yang mengganti nama gelarnya sendiri menjadi Ngarsa Dalem Sampeyan Dalem Ingkang Sinuwun Sri Sultan Hamengkubawono Ingkang Jumeneng Kasepuluh Suryaning Mataram Senapati Ing Ngalogo Langgenging Bawono Langgeng, Langgenging Toto Panotogomo". Dari gelar itu, tampak bahwa Sultan HB X menghilangkan kata "Kalifatullah" diganti dengan "Langgeng Ing Toto Panotogomo". Pelepasan gelar Kalifatullah ini dapat dikatakan sebagai pelucutan simbolis kedekatan khusus Islam dengan Keraton Yogyakarta. Dapat dikatakan bahwa raja Keraton Yogyakarta, tampaknya, berusaha berdiri di atas semua agama. Dalam analisis Dardias (2016: 45) dijelaskan bahwa komunitas Islam yang menopang sisi ke-Islaman Kasultanan Yogyakarta (Muhammadiyah maupun Nahdlatul Ulama) menentang penggantian namanya (Sabda Raja) dan termasuk penunjukan putri Mahkota (Dawuh Raja), karena keduanya bertentangan dengan nilai-nilai Islam, dan tidak sesuai dengan paugeran (aturan) yang selama ini dianut Kasultanan. Heni Astriyanto, Ketua Muhammadiyah Kota Yogyakarta (sebagaimana dikutip dari Dardias, 2016: 45) mengatakan bahwa "penghapusan gelar pemimpin agama itu praktis mengubah pakem Keraton Yogya yang selama ini beridentitas sebagai Kerajaan Mataram Islam".

Jadi, dalam pandangan penulis, justru di tengah fenomena Islamisasi sosial yang menguat saat ini, Keraton Yogyakarta ingin menunjukkan posisi (publiknya) yang netral berdiri di atas semua agama. Hal ini menjadi penanda babak baru dalam hubungan Hindu-Islam dalam perkembangan Kerajaan Mataram di era kontemporer Indonesia. Jika dari tahun 1975 sampai sebelum penggantian gelar Sultan HB X, terlihat fase kedekatan Keraton Yogyakarta terhadap nilai-nilai Islam, sejak dihapusnya gelar Kalifatullah pada Sultan HB X tersebut dimulailah era baru aristokrasi yang lebih netral karena melucuti simbol-simbol dan nilai-nilai Islam yang sebelumnya dieksplisitkan. Namun, pada kondisi ini, elemen Hindu-Jawa masih tetap kuat mewarnai kehidupan spiritual terdalam. Terbukti misalnya, Sultan HB X menjelaskan bahwa Sabda dan Dawuh raja yang diumumkannya didasari oleh wahyu Tuhan yang datang secara tiba-tiba (Vicka, http://jateng. metrotvnews.com, 8 Mei 2015), serta penggunaan berbagai pusaka dan elemennya dalam ritual Hindu-Islam Jawa pada serangkaian persistiwa Sabda dan Dawuh Raja.

Kedua, penghapusan gelar Sultan HB X sebagai pemimpin agama atau Kalifatullah Sayidin Panatagama (pimpinan agama dan wakil Tuhan di bumi), yang kemudian diikuti dengan Sabda Raja memberikan gelar pada GKR Pembayun dengan gelar Mangkubumi, yang berarti diangkat menjadi putri mahkota dan akan menjadi penerus tahta memperlihatkan upaya melepaskan Keraton dari nilai-nilai Islam atau paugeran yang selama ini (dianggap) menghambat kiprah perempuan dalam konsep kuasa Jawa. Mencermati komentar Sukiman, ketua Paguyuban Dukuh DIY Semar Sembogo, yang mengatakan "Ya kalau namanya, Sayidin Panatagama itu namanya imam, selama berkaitan dengan 'din' , yaitu agama (Islam), imam itu kan kakung (laki-laki)" (Siswoyo \& Waskita, 2015; sebagaimana dikutip dari Dardias, 2016; 45). Mencermati komentar salah satu elemen masyarakat yang sebenarnya merupakan pendukung setia Sultan HB X, tetapi tidak setuju dengan Sabda dan Dawuh Raja. Tampak jelas adanya hubungan langsung antara nilai Islam dalam gelar Kalifatullah Sayidin Panatagama (pimpinan agama dan wakil Tuhan di bumi) yang melekat pada diri seorang raja Keraton Yogyakarta, dalam hal ini Sultan HB X, dengan aspek gender. Jika terus menggunakan paugeran ini, hanya laki-laki yang berhak menjadi penerus tahta, karena pada umumnya kepercayaan klasik Islam - sebagaimana diungkapkan Sukiman di atas-mempercayai hanya laki-laki yang bisa menjadi imam (Islam) dan wakil Tuhan di bumi. Dalam konteks kekinian, paugeran tersebut tidak sejalan dengan 
semangat kesetaraan gender. Oleh karena itu, jika Keraton Yogyakarta hendak sejalan dengan perkembangan kesetaraan dan keadilan gender, pranata atau paugeran yang menjadi tembok penghambat utama haruslah diubah. Hal itu dilakukan dengan menghapuskan dan mengganti gelar yang kental pengaruh Islamnya "Kalifatullah Sayidin Panatagama" pada diri Sultan HB X, agar penerusnya (yang dapat seorang laki-laki atau perempuan) tidak harus terbebani dengan ekpektasi tugas menjadi imam (Islam) dan wakil Tuhan di bumi sebagaimana ekspektasi nilai-nilai Islam yang lazimnya dulu melekat pada diri seorang raja Keraton Yogyakarta.

Ketiga, pemberian gelar baru GKR Pembayun menjadi GKR Mangkubumi sebagai penanda pengangkatan putri makhota dapat dilihat sebagai salah satu potret perubahan konsep keluarga dalam Keraton Yogyakarta. Jika dahulu melazimkan poligami, maka sekarang norma itu berubah ke arah monogami. Hal ini tentu harus diletakkan dalam perkembangan besar demokratisasi dan isu kesetaraan gender di Indonesia pascaOrde Baru (setelah lengsernya Suharto tahun 1998). Pada masa lalu, poligami adalah hal lazim dilakukan oleh para raja Mataram. Terdapat istilah "parameswari" atau "tuan putri yang terutama" sebagai sebutan untuk istri raja atau dalam bahasa Jawa sebagai "garwa" (Moedjanto, 1987: 137). Pada masa lalu, seorang raja, yaitu Sultan Raja Yogyakarta atau Sunan (Raja Surakarta), pada umumnya memiliki dua orang parameswari yaitu Ratu Kulon atau Ratu pertama (the first Queen) yang memiliki kedudukan lebih tinggi, sedangkan yang kedua adalah Ratu Wetan (the second Queen) yang memiliki kedudukan lebih rendah. Kedua parameswari berhak duduk bersebelahan di kanan dan kiri Raja atau berjalan berdampingan dengan raja (Moedjanto, 1987: 138). Di luar parameswari, terdapat "selir" atau "garwa ampeyan" atau "klangenan" sebagai seorang wanita yang telah diikat oleh tali kekeluargaan oleh seorang laki-laki tetapi tidak berstatus sebagai istri sah, biasanya berasal dari wanita kelas bawah atau bangsawan rendahan. Apabila kemudian bangsawan dan selir memiliki anak, maka selir akan dinikahi secara simbolis agar anak yang terlahir dapat menggunakan gelar kebangsawanan dan sekaligus memperoleh hak warisan (Moedjanto, 1987: 129). Sudah lazim dalam sejarah kerajaan Mataram, jika parameswari tidak memiliki anak laki-laki, raja akan memilih anak laki-laki dari para selir yang dikehendaki untuk menjadi pewaris tahta.

Pada masa lalu lumrah bagi seorang raja memiliki banyak istri dan selir. Namun, hal ini tidak dilakukan oleh Sultan HB X. Sultan HB X tidak melakukan poligami. Bisa jadi hal ini adalah salah satu bentuk perubahan dalam konsep keluarga Keraton, yang tidak lagi menganut poligami. Bagaimanapun juga Keraton Yogyakarta di bawah Sultan HB X berada pada masa globalisasi dan demokratisasi, yang dilingkupi oleh berbagai isu kesetaraan gender yang menghendaki kesamaan kedudukan perempuan dan laki-laki. Harus diingat pula bahwa istri dari Sultan HB X, yaitu Gusti Kanjeng Ratu Hemas (GKR Hemas), adalah seorang aktivis perempuan, ketua Presidium Nasional Kaukus Perempuan Parlemen Republik Indonesia dan penggiat kesetaraan gender (lihat Syamsi, 2012). Maka, berbagai konteks kekinian ini menjadi latar belakang kuat mulai berubahnya konsep keluarga dalam Keraton Yogyakarta, dari kecenderungan poligami ke penerimaan terhadap monogami sebagai sebuah kelaziman. Sultan HB X tidak memiliki putra laki-laki. Kesemua anaknya adalah perempuan, yaitu Gusti Raden Ayu (GRA) Nurmalita Sari (Gusti Kanjeng Ratu Pembayun), GRA Nurmagupita (GKR Condrokirono), GRA Nurkamnari Dewi (GKR Maduretno), GRA Nurabra Juwita (GKR Hayu), dan GRA Nurastuti Wirajeni (GKR Bendoro) (Kristanto, 2015). Dalam konteks ini, salah satu akademisi Guru Besar Sejarah UGM, Prof. Djoko Suryo, menilai pengangkatan GKR Pembayun sebagai putri mahkota merupakan hal yang sudah lazim dalam sejarah kerajaan di Nusantara dan karena Sultan HB X tidak lagi berpoligami seperti Sultan sebelumnya mengakibatkan Sultan tidak memiliki banyak pilihan untuk memilih calon penerusnya, sebagaimana raja-raja dahulu yang dapat mengambil putra dari para selir (galamedianews.com, 6 Mei 2015).

Keempat, peristiwa ini menandai pergeseran konsep kuasa Jawa mengenai kepantasan perempuan memegang kuasa Jawa dan perempuan tidak dipandang sebelah mata sekedar menjalankan peran prokreasi (reproduksi) untuk melahirkan anak laki-laki penerus tahta. Pemberian gelar GKR Mangkubumi pada GKR Pembayun dapat ditafsirkan bahwa perempuan yang dulunya dianggap tidak memiliki potensi memiliki kuasa Jawa, kini dipersepsikan memiliki 
potensi yang sama dengan laki-laki mengemban kuasa Jawa. Selain itu, perempuan Jawa tidak lagi dipandang semata-mata hanya mengemban peran prokreasi (reproduksi) untuk melahirkan anak laki-laki bagi penerus tahta raja-raja Mataram (bagi perempuan istri raja khususnya), seperti yang terjadi pada masa lalu. Kini perempuan, dalam kosmologi Jawa, dianggap sama potensinya dengan laki-laki untuk berperan memimpin dan mewarnai perkembangan peradaban Jawa kontemporer.

Kelima, analisis bahwa peristiwa ini dapat menjadi penanda awal pergeseran konsep kuasa Jawa juga diperkuat oleh fakta adanya perubahan cara pandang atau persepsi dalam masyarakat Jawa mengenai peran dan posisi perempuan dan laki-laki. Dalam konsep Jawa pada masa lalu, laki-laki dianggap atau dipersepsikan sebagai inti dari keluarga Jawa, menjadi pemimpin dalam keluarga dan di ruang publik sedangkan perempuan diposisikan sebagai yang mendukung suami. Perempuan diposisikan di tempat belakang, yang bertanggungjawab mengurus kebutuhan rumah atau dapur dengan kata-kata konco wingking, yang mengindikasikan subordinasi perempuan Jawa (Handayani dan Novianto, 2011: 117-118). Namun demikian, dalam konteks kekinian persepsi semacam itu tidak lagi dipercaya dan telah mengalami perubahan (Sukri \& Sofwan, 2001). Hal ini terjadi karena pengaruh pendidikan, perkembangan ekonomi, dan perubahan sosial yang memungkinkan semakin banyak perempuan Jawa mengenyam pendidikan tinggi, serta diiringi dengan keterbukaan masyarakat terhadap gagasan partisipasi dan kesetaraan gender. Penelitian penulis (Dewi, 2015) terhadap tiga perempuan Jawa terpilih sebagai kepala daerah di Kebumen, Pekalongan, dan Banyuwangi menunjukkan bahwa persepsi perempuan Jawa sebagai konco wingking tidak lagi mereka rasakan dan tidak ada hambatan berarti secara kultural dalam kiprah mereka sebagai pemimpin di ruang publik.

Oleh karena itu, sangat masuk akal jika peristiwa pengangkatan GKR Pembayun sebagai putri mahkota, dapat diterjemahkan sebagai tanda pergeseran konsep kuasa Jawa, yang kini lebih mengakui kapasitas perempuan sebagaimana halnya laki-laki untuk memegang kendali kuasa Jawa. Diibaratkan sebuah lingkaran dengan dua lapisan luar dan dalam, maka logikanya jika lapisan luar (kiprah perempuan Jawa dalam berbagai bidang, termasuk menjadi pemimpin politik) telah mengalami perubahan, tentu logis jika lapisan inti di dalam lingkaran terdalam, yaitu konsep kuasa Jawa, telah mengalami perubahan atau pergeseran terlebih dahulu, ke arah kesetaraan gender.

Kelima poin tersebut bagi sebagian kalangan mungkin tidak meyakinkan. Sebagian besar kalangan menerjemahkan peristiwa tersebut sebagai perebutan kekuasaan internal Keraton Yogyakarta, mengingat adanya perpecahan internal antara para saudara kandung Sultan yang merasa berhak menjadi penerus tahta. Jika ditelisik dalam sejarah, ternyata suksesi raja-raja Mataram selalu diwarnai dengan dinamika atau penentangan dalam proses pergantian tahta. Moedjanto (1987: 29) mengatakan bahwa setiap raja Mataram, sejak fase awal naik tahta, kemudian menjabat pada dasarnya selalu merasa terancam, yang dapat dilihat dari permaklumam kenaikan raja tersebut biasanya dilakukan oleh para sesepuh dinasti Mataram, berbunyi: "atas perkenan raja yang mendahului, putranya.... menggantikan di atas tahta; maka bila ada yang tidak setuju ayo maju saja, saya yang akan menghadapi!". Dardias (2016: 36) juga menegaskan bahwa dalam tradisi aristokrasi agraris di Mataram, pemimpin politik ditentukan oleh kontestasi internal di antara anggota keluarga inti kerajaan. Jadi, sebenarnya sejarah telah mencatat bahwa setiap menjelang suksesi atau pergantian tahta raja Keraton Yogyakarta, selalu dibarengi dengan ketegangan dalam memperebutkan tahta tersebut. Memahami hal sedemikian, maka dinamika dan kontroversi antarsaudara Sultan HB X yang mengiringi prosesi pengangkatan GKR Pembayun sebagai putri Mahkota harus dibaca lebih dari sekedar peristiwa politis perebutan tahta semata, yang sudah lazim dipahami.

Oleh karena itu, upaya untuk membaca dan menafsirkan peristiwa itu secara berbeda, lebih dari sekedar persoalan politik, harus dilakukan sebagaimana upaya tulisan ini. Pada akhirnya, tulisan ini menggarisbawahi bahwa serangkaian upacara pemberian gelar baru pada GKR Pembayun sebagai pertanda pengangkatan putri mahkota yang akan menjadi penerus tahta, menyiratkan narasi penting, yaitu kuasa Jawa kultural relijius politis, yang pada masa lalu selalu berada di tangan laki-laki sebagai pengontrol kosmologi Jawa, kini telah mengalami pergeseran, jika belum dapat disebut perubahan. Perempuan yang dulunya dalam 
konsepsi kuasa Jawa hanya berada pada posisi pinggiran, tidak dilihat sebagai subyek potensial, sekedar dibutuhkan karena fungsi prokreasi untuk melahirkan anak laki-laki sebagai penerus tahta. Semua hal itu mengalami perubahan. Perempuan mulai berada pada sentral konsep kuasa Jawa, dipercaya mampu memiliki potensi memegang kuasa, dan menjadi pemimpin peradaban, sejajar dengan dengan laki-laki.

\section{Penutup}

Tulisan ini memberikan analisis yang berbeda terhadap peristiwa pemberian gelar baru pada GKR Pembayun mejadi GKR Mangkubumi, yang berarti diangkatnya Ia sebagai putri mahkota, dan dipercaya akan menjadi penerus tahta Keraton Yogyakarta. Alih-alih terjebak dalam analisis jangka pendek, tulisan ini menawarkan analisis yang lebih mendalam dengan perspektif gender mengenai kemungkinan pergeseran konsep kuasa Jawa, khususnya terkait dengan peran dan posisi perempuan di dalamnya.

Tulisan ini menunjukkan bahwa peristiwa tersebut menandai adanya narasi baru mengenai konsep kuasa Jawa kontemporer. Jika pada masa lalu, konsep kuasa Jawa berpusat pada narasi kepemimpinan kultural relijius politis yang dipercaya hanya dimiliki oleh para laki-laki, sebagai yang mampu memiliki potensi halus, mengendalikan diri, menerima wahyu dan mengemban kekuatan magis kemenyatuan dengan Tuhan, saat ini perempuan juga telah diposisikan sebagai yang memiliki potensi kuasa sejajar dengan laki-laki dan berhak menjadi pemimpin dalam kosmologi Jawa, dan kemudian menjadi pemimpin publik. Dalam konsep kuasa Jawa masa lalu, perempuan berada pada posisi pinggiran dibutuhkan karena fungsi prokreasi (reproduksi) untuk melahirkan keturunan. Namun, dalam konsep kuasa Jawa masa kini, perempuan telah dipercaya memiliki potensi yang sama dengan laki-laki, untuk dapat mengemban kuasa (dengan berbagai ritual dan standar pengendalian diri sebagaimana dijelaskan sebelumnya) untuk menerima wahyu Tuhan dan pemimpin peradaban. Jadi, dapat dikatakan telah terjadi pergeseran konsep kuasa Jawa.

Tulisan ini juga menengarai adanya babak baru dalam hubungan Hindu-Islam dalam perkembangan Kerajaan Mataram di era kontemporer Indonesia. Jika dari tahun 1975 sampai sebelum penggantian gelar Sultan HB X terlihat fase kedekatan Keraton Yogyakarta terhadap nilai-nilai Islam, sejak peristiwa dihapusnya gelar Kalifatullah pada Sultan HB X itu ada indikasi mulainya era baru aristokrasi yang lebih netral karena melucuti simbol-simbol dan nilai-nilai Islam yang sebelumnya dieksplisitkan. Justru di tengah tengah fenomena Islamisasi sosial yang menguat saat ini, Keraton Yogyakarta tampaknya ingin menunjukkan posisi (publiknya) yang netral berdiri di atas semua agama. Namun pada kondisi sedemikian, elemen Hindu-Jawa masih tetap kuat mewarnai kehidupan spiritual terdalam. Semua perkembangan tersebut terjadi karena Keraton Yogyakarta hidup dan berkembang dalam konteks yang berbeda dari masa lalu, berupa globalisasi, kuatnya Islamisasi sosial, demokratisasi, dan persoalan kesetaraan gender yang dihadapi pada masa kini.

Upaya untuk mengungkap secara lebih mendalam temuan tulisan ini mengenai indikasi pergeseran konsep kuasa Jawa, yang memberikan peran dan posisi sejajar kepada perempuan untuk dapat memegang kuasa, semestinya juga disambut terbuka dan kooperatif oleh Keraton Yogyakarta. Oleh karena itu, tulisan ini diakhiri dengan mengajak pembaca dan peneliti untuk terus menggarap persoalan ini secara serius. Diperlukan kajian lanjutan yang mendalam untuk mampu secara utuh menyajikan potret terkini mengenai pergeseran konsep kuasa Jawa, dikaitkan dengan peran dan posisi perempuan Jawa masa kini. Sebuah kajian yang tidak saja menantang, tetapi juga akan memberikan kontribusi berharga dalam memberikan pemahan baru mengenai konsep kuasa Jawa kekinian, gender, dan politik serta peran Keraton Yogyakart dalam mendorong kesetaraan gender.

\section{Daftar Pustaka}

\section{Buku}

Anderson, Benedict R.O'G. (1972a)."The Idea of Power in Javanese Culture," dalam Culture and Politics in Indonesia, ed. Claire Holt. Ithaca and London: Cornell University Press.

Anderson, Benedict R.O'G. (1990b). Language and Power: Exploring Political Cultures in Indonesia. Ithaca and London: Cornell University Press. 
Brenner, Suzanne A. (1995). "Why Women Rule the Roost: Rethinking Javanese Ideologies of Gender and Self-Control," dalam Bewitching Women, Pious Men: Gender and Body Politics in Southeast Asia, ed. Aihwa Ong and Michael G. Peletz. Berkeley, Los Angeles, London: University California Press.

Brenner, Suzanne A. (1995). "Why Women Rule the Roost: Rethinking Javanese Ideologies of Gender and Self-Control," dalam Bewitching Women, Pious Men: Gender and Body Politics in Southeast Asia, eds. Aihwa Ong and Michael G. Peletz. Berkeley, Los Angeles, London: University California Press.

Dewi, Kurniawati Hastuti.( 2015). Indonesian Women and Local Politics: Islam, Gender and Networks in Post-Suharto Indonesia. Singapore: National University of Singapore Press and Kyoto University Press.

Djajadningrat-Nieuwenhuis, Madelon. (1987). "Ibuism And Priyayization: Path to Power?", dalam Indonesian Women in Focus: Past And Present Notions, eds. Elsbeth Locher-Scholten dan Anke Niehof. The Netherlands: Foris Publications.

Errington, Shelly. (1990). "Recasting Sex, Gender, and Power: A Theoretical and Regional Overview," dalam Power and Difference: Gender in Island Southeast Asia. eds. Jane Monnig Atkinson and Shelly Errington. Stanford, California: Stanford University Press.

Florida, Nancy K. (1995). Writing the Past, Inscribing the Future: History As Prophecy in Colonial Java. Durham and London: Duke University Press.

Geertz, Clifford. (1960a). The Religion of Java. London: The Free Press of Glencoe.

Geertz, Hildred. (1961b). The Javanese Family: A Study of Kinship and Socialization. United States of America: The Free Press of Glencoe Inc.

Handayani, Christina S.\& Novianto, Ardhian. (2011). Kuasa Wanita Jawa, ed.3. Yogyakarta: LKiS.
Hatley, Barbara. (1990). "Theatrical Imagery and Gender Ideology in Java," dalam Power and Difference: Gender in Island Southeast Asia, eds. Jane Monnig Atkinson and Shelly Errington. Stanford, California: Stanford University Press.

Jay, Robert R.( 1969b). Javanese Villagers: Social Relations in Rural Modjokuto. Cambridge, Massachusetts, London: The MIT Press.

Jay, Robert R.( 1963a). Religion and Politics in Rural Central Java: Cultural Report Series No.12. USA: Southeast Asian Studies, Yale University.

Keeler, Ward. (1990). "Speaking Gender in Java," dalam Power and Difference: Gender in Island Southeast Asia, eds. Jane Monnig Atkinson and Shelly Errington. Stanford, California: Stanford University Press.

Koentjaraningrat, R.M. (1957a). A Preliminary Description of The Javanese Kinship System, Cultural Report Series. Yale University: Southeast Asia Studies.

Koentjaraningrat, Reviewed Work Hildred Geertz. (Aug 1962b). The Javanese Family: A Study of Kinship and Socialization, American Anthropologist New Series 64, no. 4: 874, http://www.jstor.org/stable/667817 (accessed November 9, 2008).

Koentjaraningrat. (1985d). Javanese Culture, Javanese Culture. Oxford, New York: Oxford University Press.

Koentjaraningrat. (1980c). "Javanese Terms For God And Supernatural Beings And The Idea Of Power," dalam Men, Meaning And History: Essays in Honour of H.G. Schulte Nordholt, eds. R. Schefold, J.W. Schoorl and J. Tennekes. The Hague: Martinus Nijhoff.

Masaaki, Okamoto, Atsushi Ota and Ahmad Suaedy (ed). (2010). Islam in Contention: Rethinking Islam and State in Indonesia. Jakarta: The Wahid Institute, CSEAS, CAPAS.

Moedjanto, G. (1987). Konsep Kekuasaan Jawa: Penerapannya oleh Raja-Raja Mataram. Yogyakarta: Penerbit Kanisius. 
Mulder, Niels. (2001). Mistisisme Jawa: Ideologi di Indonesia. Yogyakarta: LKiS.

Robinson, Kathryn. (2009). Gender, Islam and Democracy in Indonesia. USA and Canada: Routledge.

Susetya, Wawan. (2016). Pemimpin Masa Kini \& Budaya Jawa: Menghidupkan Kembali Nilai-Nilai Kepribadian dan Kepemimpinan dalam Perspektif Jawa. Jakarta: Kompas Gramedia.

Sullivan, Norma. (1994). Masters and Managers: A Study of Gender Relations in Urban Java. NSW, Australia: Allen and Unwin.

Sukri, Sri Suhandjati, and Sofwan, Ridin. (2011). Perempuan dan Seksualitas dalam Tradisi Jawa. Yogyakarta: Gama Media.

Syamsi, Indra (ed). (2012). G.K.R Hemas Ratu di Hati Rakyat. Jakarta: Kompas Gramedia.

Vreede-De Stuers, Cora. (1960). The Indonesian Woman: Struggles and Achievements. France: Mouton \& Co.

Woodward, Mark R. (1989). Islam in Java: Normative Piety and Mysticism in the Sultanate of Yogyakarta. Tucson: The University of Arizona Press.

\section{Jurnal}

Dardias, Bayu. (Juni 2016). "Menyiapkan Sultan Perempuan: Legitimasi Langit dan Efektifitas Rezim Sultan Hamengkubuwono X", Masyarakat Indonesia, vol. 42, no. 1: 31-49.

Koentjaraningrat. Reviewed Work Hildred Geertz. (Aug 1962). The Javanese Family: A Study of Kinship and Socialization, American Anthropologist New Series 64, no. 4: 874, http://www.jstor.org/stable/667817 (accessed November 9, 2008).

Wardani, Laksmi Kusuma. (Januari-Maret 2012). "Pengaruh Pandangan SosioKultural Sultan Hamengku Buwana IX terhadap Eksistensi Keraton Yogyakarta," Jurnal Masyarakat, Kebudayaan dan Politik, vol. 25, no. 1: 56.

\section{Paper}

Djohan, Djohermansyah. Dirjen Otonomi Daerah Kementerian Dalam Negeri Republik Indonesia, "Dinamika Dan Ekses Pilkada Langsung," paper disampaikan dalam FGD tim Pemilukada, 26 Agustus 2013 di LIPI Jakarta.

\section{Berita Daring}

Antara, "Sultan: Polemik Persyaratan Calon Gubernur DIY Selesai", didapat dari Kompas.com, Rabu, 1 April 2015, http://regional.kompas.com/read/2015/0 4/01/08594431/Sultan.Polemik.Persyar atan.Calon.Gubernur.DIY.Selesai (diakses 29 November 2016)

Detiknews, "Polemik Sabda Raja: Mengintip Rupa Watu Gilang, Singgasana yang akan Diduduki GKR Mangkubumi", Detiknews, Senin 11 May 2015, http://news.detik.com/berita/2911806/m engintip-rupa-watu-gilang-singgasanayang-akan-diduduki-gkr-mangkubumi (diakses 12 Januari 2017)

Fachrudin, Fachri. "Syarat Calon Gubernur di UU Keistimewaan DI Yogyakarta Digugat ke MK", Kompas.com, Kamis, 17 November 2016, http://nasional. kompas.com/read/2016/11/17/15384411 /syarat.calon.gubernur.di.uu.keistimewa an.di.yogyakarta.digugat.ke.mk (diakses 29 November 2016)

Firdaus, Haris. "Pengangkatan GKR Pembayun Berpotensi Timbulkan Perdebatan", Kompas, 6 Mei 2015, http://print. kompas.com/baca/2015/05/06/Pengangk atan-GKR-Pembayun-BerpotensiTimbulkan-Per?utm_source=bacajuga (diakses 18 Maret 2016)

galamedianews.com . "Mungkinkan GKR Pebayun jadi Ratu Pertama Kesultanan Ngayogyakarta Hadiningrat?," Rabu, 6 Mei 2015, http://www.galamedianews. com/nasional/21512/mungkinkan-gkrpebayun-jadi-ratu-pertama-kesultananngayogyakarta-hadiningrat.html (diakses 18 Maret 2016)

Gugatan Keistimewaan Jogjakarta Ditotak Mahkamah Konstitusi”, tribunmadura. com, 19 Agustus 2016, http://tribun madura.com/gugatan-keistimewaan- 
jogjakarta-ditotak-mahkamah-

konstitusi/ (diakses 8 Desember 2016)

Hasanudin, Ujang. "GKR Pembayun Jadi Putri Mahkota, Bergelar GKR Mangkubumi”, Solopos.com, Selasa, 5 Mei 2015 19:50 WIB, http://www.solopos.com/2015/ 05/05/gkr-pembayun-jadi-putrimahkota-bergelar-gkr-mangkubumi601293 (diakses 18 Maret 2016).

Jppn. "Detik-detik saat GKR Pembayun Gemetaran Duduk di Atas Watu Gilang”, Jppn.com. Kamis, 14 Mei 2015 http://www.jpnn.com/news/detik-detiksaat-gkr-pembayun-gemetaran-dudukdi-atas-watu-gilang?page $=2$ (diakses 12 Januari 2016)

Kabar Kota. "Ini Kekhawatiran Forum LSM DIY Jika Uji Materiil UU Keistimewaan DIY Dikabulkan", kabarkota.com, 18 November 2016, https://kabarkota.com/ ini-kekhawatiran-forum-lsm-diy-jikauji-materiil-uu-keistimewaan-diydikabulkan/ (diakses 7 Desember 2016).

Kristanto, Tri Agung. "Sultan HB X, Tradisi Suksesi Keraton Yogyakarta yang Berubah", Kompas, 8 Mei 2015, http://print.kompas.com/baca/2015/05/0 8/Sultan-HB-X\%2c-Tradisi-SuksesiKeraton-Yogyakarta-ya (diakses 18 Maret 2016).
Rachmat, Muhammad Sabarudin. "Kemendagri: Putri Mahkota Tak Bisa Jadi Gubernur Yogyakarta," (Okezone) Kamis, 7 Mei 2015, http://news.okezone.com/read/ 2015/05/06/337/1145738/kemendagriputri-mahkota-tak-bisa-jadi-gubernuryogyakarta (diakses 18 Maret 2016).

Rusdiana, Pito. "Berikut Isi Utuh Sabda Raja Yogya", Antara, dikutip dari Tempo.co, Sabtu, 09 Mei $2015 \mid$ 00:49 WIB, https://m.tempo.co/read/news/2015/05/0 9/078664761/berikut-isi-utuh-sabdaraja-yogya (diakses 3 Januari 2017).

Rudiana, Pito Agustin. "Sabda Raja dan Apa Makna di Balik Pergantian Gelar Sultan", Antara, dikutip dari Tempo.co, Sabtu, 09 Mei 2015 | 00:19 WIB https://m.tempo.co/read/news/2015/05/0 9/078664758/sabda-raja-dan-apamakna-di-balik-pergantian-gelar-sultan (diakses 3 Januari 2017).

Sari, Febriana Shinta. "GKR Pembayun Mengaku Terkejut Tahu Dirinya Dijadikan Calon Ratu", Selasa, 05/05/2015 19:44 WIB, http://kbr.id/052015/grk_pembayun_mengaku_terkejut _tahu_dirinya_dijadikan_calon_ratu_/70 552.html (diakses 28 November 2016).

Vicka, Patricia. "Cerita Sultan Saat Dapat Wahyu Sabda Raja", Jumat, 8 Mei 2015, http://jateng.metrotvnews.com/ $\mathrm{read} / 2015 / 05 / 08 / 123994 /$ cerita-sultansaat-dapat-wahyu-sabda-raja (diakses 21 Desember 2016). 